\title{
Differences exist in the immunoblotting profiles of cyst and trophozoite antigens of Pneumocystis carinii
}

\author{
J. M. W. ChATTERTON, A. W. L. JOSS, T. H. PENNINGTON* and D. O. HO-YEN
}

Microbiology Department, Raigmore Hospital, Inverness IV2 3UJ and * Department of Medical Microbiology, University of Aberdeen, Foresterhill, Aberdeen AB9 2ZD

\begin{abstract}
Summary. The antigenic profiles of Pneumocystis carinii trophozoites and cysts were compared by immunoblotting with hyperimmune rat sera against cyst and trophozoite antigens. Strong bands corresponding to proteins of $50-60 \mathrm{kDa}$ and $104 \mathrm{kDa}$ were demonstrated in cyst and trophozoite antigens by all antisera. Additional prominent proteins of 81 and $63 \mathrm{kDa}$ and less prominent proteins of $88,73,69$ and $37 \mathrm{kDa}$ were found only in trophozoite antigen. The latter proteins were recognised by anti-trophozoite and anti-cyst antisera but the 81- and 63-kDa proteins were associated specifically with trophozoites. With cyst-rich antigen, antibodies to the 50-60-kDa protein were detected in only two of 14 sera from P. carinii pneumonia (PCP)-positive rats. With trophozoite-rich antigen, 11 of 24 rats with PCP and one of 18 PCP-negative animals had antibodies to both the 50-60 kDa and 104$\mathrm{kDa}$ antigens. Antibodies to the $81-$ or $63-\mathrm{kDa}$ antigens were demonstrated in 15 of $24 \mathrm{PCP}-$ positive animals and none of the PCP-negative animals. The use of trophozoites rather than cysts increased the sensitivity of immunoblotting. As trophozoites predominate in PCP, antibody to trophozoite-specific antigens rather than common cyst and trophozoite antigens is likely to be a more useful marker of current infection.
\end{abstract}

\section{Introduction}

Investigations in Pneumocystis carinii pneumonia (PCP) have focused on the resistant and easily identified cyst rather than the fragile trophozoite, ${ }^{1}$ even though the latter can account for up to $99 \%$ of the parasites in a bronchoalveolar lavage sample. ${ }^{2}$ It has been assumed also that cysts and trophozoites are antigenically identical. Reports that trophozoites react in immunofluorescence tests with antisera against cysts $^{3,4}$ indicate that they share common antigens, but such evidence does not exclude the possibility of unique cyst or trophozoite antigens. Nevertheless, the convention has been to characterise the antigens and antisera used in serological tests in terms of numbers of cysts or reactivity with cysts. Trophozoites have been largely ignored in such analyses. ${ }^{1}$

Identification of specific antigens that are important in the immune response to $P$. carinii may allow the development of more specific immunological tests. Most Western immunoblotting studies have investigated material that either contains all stages of the parasite or has been prepared by methods that preferentially destroy trophozoites. Only one study

Received 7 April 1994; revised version accepted 8 Aug. 1994. has attempted to investigate cyst and trophozoite antigens separately. ${ }^{4}$ In the present study, the immunoblotting profiles of cysts and trophozoites were studied to identify the usefulness of trophozoite antigens as markers of $P$. carinii infection in the rat model.

\section{Materials and methods}

\section{$P$. carinii antigens}

PCP was induced in male Sprague-Dawley rats weighing $150 \mathrm{~g}$ (Harlan Olac Ltd, Bicester) by twiceweekly intramuscular injection of $25 \mathrm{mg}$ of hydrocortisone acetate (The Boots Company, Nottingham). Tetracycline $(1 \mathrm{mg} / \mathrm{ml})$ was added to the water supply to protect against bacterial infection. The rats were immunosuppressed for 6-8 weeks and developed autoinfection. They were killed by intraperitoneal injection of pentabarbitone sodium (Veterinary Drug Co., York), and exsanguinated. The serum was stored at $-20^{\circ} \mathrm{C}$. Giemsa, toluidine blue $\mathrm{O}^{5}$ and indirect immunofluorescence (IFA) with rat anti- $P$. carinii antiserum and fluorescein-conjugated anti-rat globulin (Dako, Denmark) were used to identify $P$. carinii cysts and trophozoites in lung imprints, washings and gradient fractions. 
P. carinii was eluted from minced, heavily infected lung by repeated stirring for $30 \mathrm{~min}$ in sterile phosphate-buffered saline, $\mathrm{pH} 7 \cdot 3$, containing mixed antibiotics (PBSM) ${ }^{6}$ Eluates containing most parasites and least host cell contamination were washed three times in PBSM by centrifugation at $2000 \mathrm{~g}$ for $15 \mathrm{~min}$ and resuspended in PBSM containing $1 \mathrm{mM}$ ethylene diamine tetraacetic acid (EDTA). Supernates from the first wash were centrifuged at $20000 \mathrm{rpm}$ for $20 \mathrm{~min}$ to deposit any remaining parasites. The ultracentrifuged (UC) pellet was stored at $-20^{\circ} \mathrm{C}$. The resuspended low speed deposits were forced three times through a fine bore needle and gross particulate contamination was removed before digestion with collagenase (Type A; Sigma) $1.5 \mathrm{mg} / \mathrm{ml}$ at $37^{\circ} \mathrm{C}$ for $1.5 \mathrm{~h}$ with gentle agitation. Discontinuous gradients of three 5-ml layers of Percoll (Pharmacia) in PBSM containing $1 \mathrm{mM}$ EDTA (density $36 \%, 16 \%$ and $8 \%$, respectively) were loaded with $5 \mathrm{ml}$ of sample and centrifuged at $2000 \mathrm{~g}$ for $15 \mathrm{~min}$. The interphases and intervening Percoll layers were collected individually from the top of the gradients by angled pipette, washed three times in PBSM and the relative numbers of cysts and trophozoites were counted. If separation was inadequate, fractionation was repeated on gradients of the same composition. Fractions were classified according to the relative numbers of cysts and trophozoites and stored at $-20^{\circ} \mathrm{C}$. Fourteen preparations of $P$. carinii antigens were made and examined: five UC pellets $(100 \%$ trophozoite); five containing $\geqslant 90 \%$ trophozoites; two containing $50-60 \%$ trophozoites and two containing $80 \%$ cysts.

\section{Control antigen}

Lungs from rats which had received immunosuppression to induce PCP, but were negative for $P$. carinii by Giemsa and toluidine blue $\mathrm{O}$ staining at postmortem examination, were processed as described for $P$. carinil-infected lung. To ensure recovery of enough protein for control antigen, only two fractions were collected: one from the sample application level to the $16 \%$ interphase; the other comprised the $16 \%$ and $36 \%$ layers (equivalent to trophozoite and cyst rich fractions above). After washing three times in PBSM they were examined by Giemsa and toluidine blue $\mathrm{O}$ staining and by IFA for $P$. carinii and stored at $-20^{\circ} \mathrm{C}$.

\section{Antisera}

Nine rats were immunised: three with a fraction containing $80 \%$ cysts; three with a fraction containing $\geqslant 90 \%$ trophozoites; and three with a fraction containing $50 \%$ cysts and trophozoites. Hyperimmune sera were prepared by inoculating rats with standardised amounts of protein with complete Freund's adjuvant. Antigen protein concentration was measured at $280 \mathrm{~nm}$ and $100 \mu \mathrm{g}$ in $0.5 \mathrm{ml}$ of PBS was then mixed with an equal volume of adjuvant and injected intramuscularly at four sites (c. $250 \mu \mathrm{L} /$ site). Booster injections of $100 \mu \mathrm{g}$ of protein, the first in incomplete Freund's adjuvant, the others without adjuvant, were given three times at 4 -week intervals; the animals were exsanguinated 2 weeks later. Sera from immunosuppressed rats were also used; 24 from animals that developed PCP and 18 from animals with no histological evidence of PCP.

\section{Immunofluorescence}

Antibodies were measured in hyperimmune sera by an indirect immunofluorescence technique reported previously. ${ }^{6}$ The antigen was prepared from unfractionated $P$. carinii washings. Hyperimmune sera were tested at dilutions ranging in two-fold steps from 1 in 32 to 1 in 1024. After addition of fluoresceinconjugated anti-rat immunoglobulin (Dako) their specificity for cyst and trophozoite antigens was assessed and compared.

\section{SDS-PAGE and immunoblotting}

Antigens were boiled for $5 \mathrm{~min}$ in a lysis buffer containing SDS $2 \%, 0.06 \mathrm{M}$ Tris- $\mathrm{HCl}(\mathrm{pH} \mathrm{6.8),} \mathrm{2-}$ mercaptoethanol $5 \%$, glycerol $10 \%$ and bromophenol blue $0.001 \%$. Electrophoresis was performed at a constant current of $6 \mathrm{~mA}$ for $16 \mathrm{~h}$ with a $3.5 \%$ stacking gel and a $12 \%$ separating gel in a discontinuous SDS buffer system. ${ }^{7} \mathrm{~A}$ mol. wt standard mixture containing myosin, $\beta$-galactosidase, phosphorylase $\mathrm{B}$, bovine albumin, egg albumin and carbonic anhydrase (Sigma) was run as a marker on the gels. Separated proteins were transferred to nitrocellulose sheets ${ }^{8}$ (pore size $0.45 \mu \mathrm{m}$ ) in an LKB 2005 Transphor Electroblotting unit at $4^{\circ} \mathrm{C}$ for $2 \mathrm{~h}$ at $0.8 \mathrm{~A}$. Lanes containing the mol. wt standards were stained with amido black (Sigma) and used to construct a calibration curve. The remainder of the sheet was blocked in PBS containing non-fat milk $5 \%$. Thereafter, strips were incubated for $16 \mathrm{~h}$ at room temperature with a 1 in 100 dilution of hyperimmune rat serum or a 1 in 20 dilution of immunosuppressed rat serum in PBS containing Tween $200.05 \%$ (PBST) and non-fat milk $5 \%$ (PBSN). Strips were washed five times in PBST then incubated for $2 \mathrm{~h}$ at room temperature in a 1 in 750 dilution of goat antirat IgG peroxidase conjugate (Sigma) in PBSN. After five washes in PBST and two in PBS strips were immersed in substrate (4-chloro-1-napthol $0.06 \%$ in methanol, hydrogen peroxide $0.014 \%$ in PBS) for $10 \mathrm{~min}$.

\section{Results}

\section{Fractionation of $P$. carinii cysts and trophozoites}

The recovery of $P$. carinii cysts and trophozoites from a Percoll gradient is summarised in table I. Cysts and trophozoites could be counted simultaneously by IFA. Cysts were identified easily and the relative pro- 
Table I. Distribution of $P$. carinii cysts and trophozoites from a discontinuous Percoll gradient

\begin{tabular}{lccr}
\hline Fraction & $\begin{array}{c}\text { Number of } \\
\text { parasites } \\
\text { counted }\end{array}$ & $\begin{array}{c}\text { Number (\%) } \\
\text { of cysts }\end{array}$ & $\begin{array}{c}\text { Number (\%) } \\
\text { of trophozoites }\end{array}$ \\
\hline Unfractionated sample & 1057 & $127(12)$ & $930(88)$ \\
Percoll gradient & 838 & $10(1 \cdot 2)$ & $828(98 \cdot 8)$ \\
1. (0-8\% interphase) & 1661 & $60(3 \cdot 6)$ & $1601(96 \cdot 4)$ \\
2. (8\% layer) & 803 & $106(13 \cdot 2)$ & $697(86 \cdot 8)$ \\
3. (8-16\% interphase) & 414 & $266(64 \cdot 3)$ & $148(35 \cdot 7)$ \\
4. (16\% layer) & 656 & $566(86 \cdot 3)$ & $90(13 \cdot 7)$ \\
5. (16-36\% interphase) & 278 & $233(83 \cdot 8)$ & $45(16 \cdot 2)$ \\
6. (36\% layer) & & & \\
\hline
\end{tabular}

portions of cysts in each fraction were confirmed by toluidine blue $\mathrm{O}$ staining. Trophozoites were more difficult to count and numbers were probably underestimated. Giemsa staining was useful in estimating host cell contamination but was abandoned for confirming trophozoite counts because of difficulties in identifying parasites. We were unable to obtain preparations that contained only cysts or trophozoites. Fractions one and two were enriched with trophozoites $(\geqslant 90 \%)$. Fractions three and four contained a mixture of trophozoites and cysts. Fractions five and six were relatively enriched with cysts $(\geqslant 80 \%)$. Host cell contamination was present in all fractions but was particularly associated with fraction five.

Separation was generally consistent between individual gradients, and fractions with similar proportions of cysts and trophozoites were pooled. Refractionation on second gradients was not pursued because although fractions were cleaner, the yield of parasites was very poor. The pellets obtained by ultracentrifugation provided the purest trophozoite preparations: although they contained host cell contamination material no cysts were observed. Irreversible clumping of parasites occurred when material was frozen and thawed, making separation impossible. Collagenase digestion and gradient fractionation did not seem to cause deterioration of the parasites; morphology was retained and reactivity in IFA was enhanced.

\section{Hyperimmune rat sera}

The final IFA antibody titres of sera from immunised rats ranged from 256 to 1024 . There was no reactivity against rat cells; therefore, sera were not absorbed with normal rat lung tissue. Cysts and trophozoites were stained to the same degree by all antisera. Only one anti-trophozoite serum appeared to react more strongly with trophozoites, with only a patchy IFA pattern with cysts.

In Western blot analyses, all hyperimmune rat sera recognised more proteins in trophozoite-rich prepara-

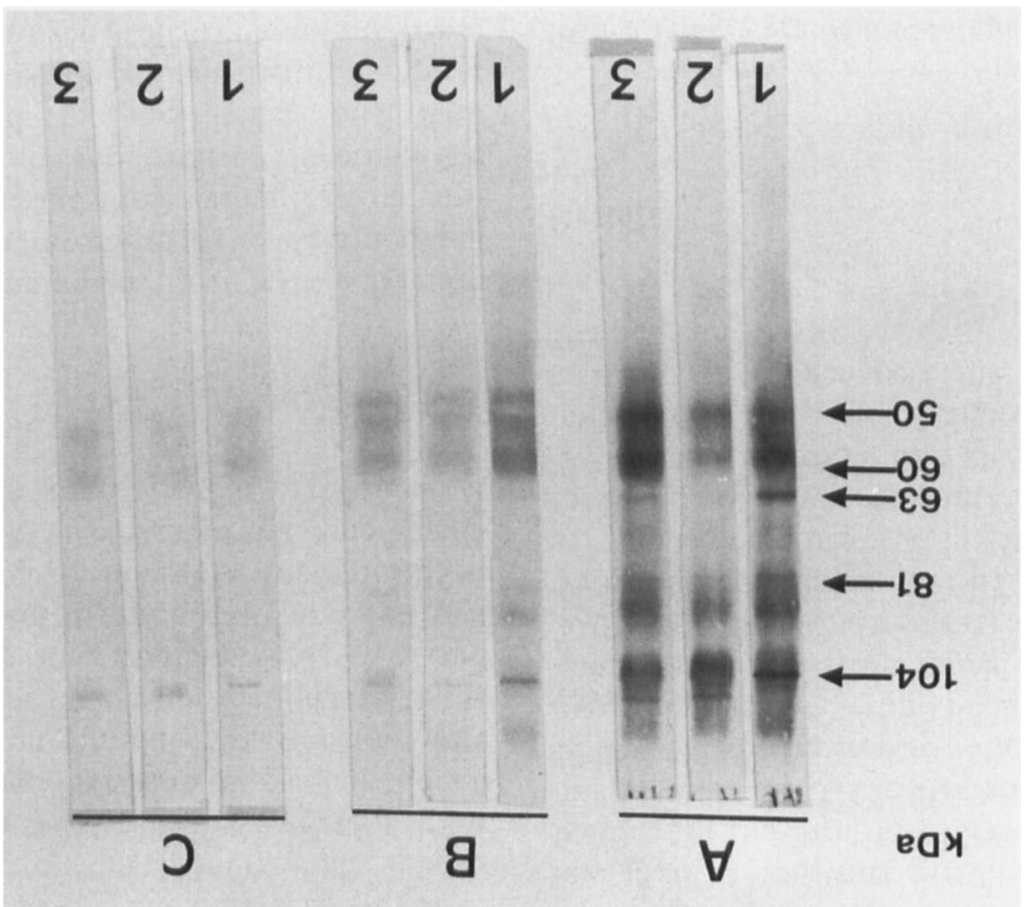

Fig. 1. Western immunoblot of: $\mathbf{A}, \geqslant 90 \%$ trophozoite antigen; $\mathbf{B}$, UC pellet antigen; $\mathbf{C}$, cyst-rich antigen, all with hyperimmune rat sera. Lane 1, anti-trophozoite antiserum; 2 , anti-cyst antiserum; $\mathbf{3}$, mixed antiserum. 
Table II. Bands detected by immunoblotting cyst and trophozoite-rich preparations with hyperimmune rat sera

\begin{tabular}{|c|c|c|c|c|c|c|c|c|c|c|c|c|c|}
\hline \multirow{3}{*}{ Antiserum } & \multirow{3}{*}{ Antigen } & \multicolumn{12}{|c|}{ Bands (kDa) detected by } \\
\hline & & \multicolumn{10}{|c|}{ both antisera } & \multicolumn{2}{|c|}{$\begin{array}{l}\text { anti-trophozoite } \\
\text { antiserum only }\end{array}$} \\
\hline & & 124 & 104 & 88 & 73 & 69 & 60 & 55 & 50 & 42 & 37 & 81 & 63 \\
\hline $\begin{array}{l}\text { Anti- } \\
\text { trophozoite }\end{array}$ & $\begin{array}{l}\text { Cyst } \\
\text { Trophozoite } \\
\text { UC }\end{array}$ & $\begin{array}{r}+ \\
+ \\
+\end{array}$ & $\begin{array}{c}+++ \\
+++ \\
++\end{array}$ & $\begin{array}{l}- \\
+ \\
+1-\end{array}$ & $\begin{array}{l}- \\
+ \\
-\end{array}$ & $\begin{array}{l}- \\
+ \\
-\end{array}$ & $\begin{array}{r}+ \\
++ \\
+\end{array}$ & $\begin{array}{r}+ \\
+ \\
+\end{array}$ & $\begin{array}{r}+ \\
+ \\
+\end{array}$ & $\begin{array}{l}- \\
+ \\
-\end{array}$ & $\begin{array}{l}- \\
+ \\
-\end{array}$ & $\begin{array}{l}-\overrightarrow{+} \\
++\end{array}$ & $\begin{array}{r}- \\
+++ \\
++\end{array}$ \\
\hline $\begin{array}{l}\text { Anti- } \\
\text { cyst }\end{array}$ & $\begin{array}{l}\text { Cyst } \\
\text { Trophozoite } \\
\text { UC }\end{array}$ & $\begin{array}{r}+ \\
++ \\
+\end{array}$ & $\begin{array}{r}++ \\
+++ \\
++\end{array}$ & $\begin{array}{l}- \\
+ \\
+/-\end{array}$ & $\begin{array}{l}- \\
+\overline{-}\end{array}$ & $+\overline{-}$ & $\begin{array}{r}+ \\
++ \\
+\end{array}$ & $\begin{array}{r}+ \\
++ \\
+\end{array}$ & $\begin{array}{r}+ \\
++ \\
+\end{array}$ & $\begin{array}{l}+ \\
+ \\
-\end{array}$ & $\begin{array}{l}- \\
+ \\
-\end{array}$ & $\begin{array}{l}- \\
- \\
-\end{array}$ & $\begin{array}{l}- \\
- \\
-\end{array}$ \\
\hline
\end{tabular}

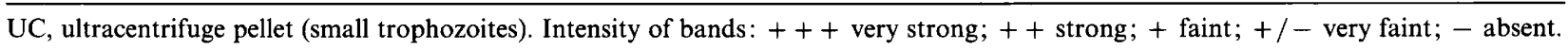

tions than in cyst-rich preparations. Although preparations with similar proportions of cysts and trophozoites and equivalent protein content showed some variation in intensity of the bands, reproducible banding patterns were established for each antigen (fig. 1, table II). Cyst preparations produced fewest protein bands and all of them were common to bands found in the trophozoite preparations. Bands at $104 \mathrm{kDa}$ and a broad band between 50 and $60 \mathrm{kDa}$ were prominent and recognised equally by antitrophozoite and anti-cyst antisera (fig. 1, table II). Bands in the $60-90 \mathrm{kDa}$ range were detected in preparations containing $\geqslant 90 \%$ trophozoites but not in cyst-rich preparations and were identified more strongly by anti-trophozoite than by anti-cyst antisera. Proteins of 81 and $63 \mathrm{kDa}$ were particularly prominent (fig. 1, table II). UC pellet preparations produced similar but fewer bands than fractions containing $\geqslant 90 \%$ trophozoites and again the $81-$ and $63-\mathrm{kDa}$ bands were the most prominent and were recognised most intensely by anti-trophozoite antisera (fig. 2, table II).

Hyperimmune rat sera produced weakly staining blots with control rat lung preparations. Only bands at $104 \mathrm{kDa}$ and $50-60 \mathrm{kDa}$ were identified and these were found in both control fractions and recognised equally by anti-trophozoite and anti-cyst antisera. The bands were very much weaker than in $P$. carinii preparations. Bands in the $60-90 \mathrm{kDa}$ range were not identified in any of the control preparations.

\section{Immunosuppressed rat sera}

Sera from immunosuppressed rats produced weaker staining blots than sera from immunised animals and recognised a restricted range of proteins. With cystrich antigen, only two of 14 rats in which $P$. carinii was demonstrated in lung tissue had detectable antibodies: in both cases antibody recognised the $50-60-\mathrm{kDa}$ protein (table III). With trophozoite-rich and UC

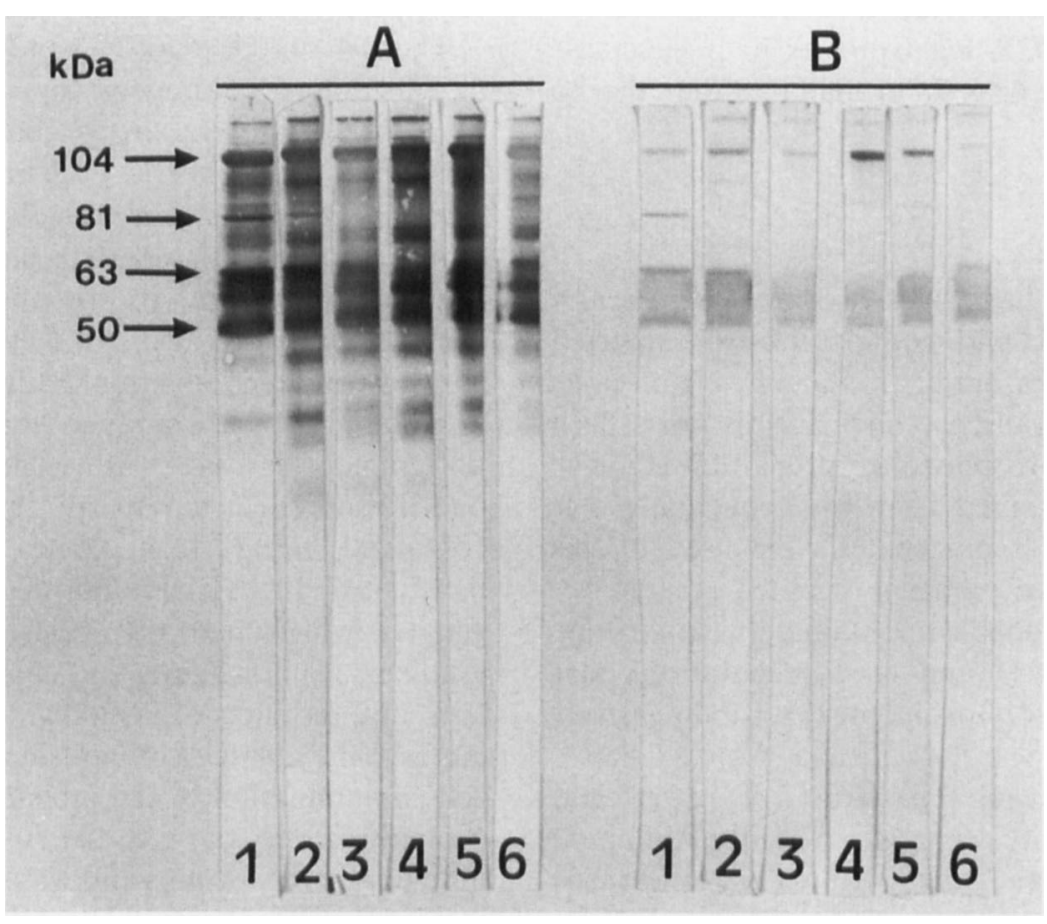

Fig. 2. Western immunoblot of: $A, \geqslant 90 \%$ trophozoite antigen; $B$, UC pellet antigen. Lanes 1 and 2 , anti-trophozoite antisera; 3 and 4 , anticyst antisera; 5 and 6 , mixed antisera. 
Table III. Bands detected in cyst and trophozoite-rich $P$. carinii antigens with sera from immunosuppressed rats

\begin{tabular}{|c|c|c|c|c|c|c|c|c|}
\hline \multirow{2}{*}{ Antigen } & \multirow{2}{*}{\multicolumn{2}{|c|}{ Number of rats }} & \multicolumn{6}{|c|}{ Number of rats with antibody to proteins $(\mathrm{kDa})$} \\
\hline & & & 124 & 104 & 81 & 63 & $50-60$ & None \\
\hline Cyst & $\begin{array}{l}\text { With PCP } \\
\text { Without PCP }\end{array}$ & $\begin{array}{l}14 \\
11\end{array}$ & $\begin{array}{l}0 \\
0\end{array}$ & $\begin{array}{l}0 \\
0\end{array}$ & $\begin{array}{l}0 \\
0\end{array}$ & $\begin{array}{l}0 \\
0\end{array}$ & $\begin{array}{l}2 \\
0\end{array}$ & $\begin{array}{l}12 \\
11\end{array}$ \\
\hline Trophozoite & $\begin{array}{l}\text { With PCP } \\
\text { Without PCP }\end{array}$ & $\begin{array}{l}24 \\
18\end{array}$ & $\begin{array}{l}2 \\
1\end{array}$ & $\begin{array}{r}16 \\
1\end{array}$ & $\begin{array}{l}9 \\
0\end{array}$ & $\begin{array}{r}12 \\
0\end{array}$ & $\begin{array}{r}13 \\
1\end{array}$ & $\begin{array}{r}4 \\
17\end{array}$ \\
\hline UC & $\begin{array}{l}\text { With PCP } \\
\text { Without PCP }\end{array}$ & $\begin{array}{l}20 \\
13\end{array}$ & $\begin{array}{l}5 \\
0\end{array}$ & $\begin{array}{l}2 \\
0\end{array}$ & $\begin{array}{l}9 \\
1\end{array}$ & $\begin{array}{r}12 \\
1\end{array}$ & $\begin{array}{l}8 \\
0\end{array}$ & $\begin{array}{r}3 \\
11\end{array}$ \\
\hline
\end{tabular}

PCP, $P$. carinii identified at necropsy; UC, ultracentrifuge pellet (small trophozoites).

pellet antigens sera were much more reactive and proteins of $124,104,81,63$ and $50-60 \mathrm{kDa}$ were recognised (table III). There was a strong association between recognition of bands and demonstration of $P$. carinii in the lung (table III). With trophozoite-rich antigen, antibodies to both the $104-$ and $50-60-\mathrm{kDa}$ proteins were identified in serum from 11 of 24 PCPpositive rats and one of 18 rats with no evidence of $P$. carinii in the lung. Fifteen of 24 PCP-positive animals had antibodies to the $63-$ or $81-\mathrm{kDa}$ proteins. This included six with antibodies only to the $63-\mathrm{kDa}$ proteins, three with antibodies only to the $81-\mathrm{kDa}$ protein and six with antibodies to both. None of 18 PCP-negative animals had antibodies to either of these proteins. In the case of the UC pellet antigen, demonstration of antibody to the $63-$ or $81-\mathrm{kDa}$ proteins was more strongly associated with evidence of $P$. carinii in the lung (table III). Of 20 PCP-positive animals, only two had antibodies to both the 104- and $50-60-\mathrm{kDa}$ proteins, whereas 16 had antibodies to the 63- or $81-\mathrm{kDa}$ proteins, including seven with antibodies only to the $63-\mathrm{kDa}$ protein, four with antibodies only to the $81-\mathrm{kDa}$ protein and five with antibodies to both. Two of 13 PCP-negative rats had detectable antibody; one to the $63-\mathrm{kDa}$ protein and the other to the $81-\mathrm{kDa}$ protein.

\section{Discussion}

Various methods have been used to separate and purify $P$. carinii cysts and trophozoites from infected lung $3,4,9,10$ but separation of trophozoites from cysts has proved to be very difficult and has only rarely been pursued., ${ }^{41}$ Pure trophozoite preparations have reportedly been obtained from rat bronchoalveolar lavage ${ }^{4,11}$ but lung homogenates were used in this study, as the yield of parasites is much greater. ${ }^{10,11}$ Like others we were unable to obtain pure trophozoite or cyst preparations ${ }^{3,9}$ and used preparations that were enriched with trophozoites or cysts and relatively free of host cells.

The immunoblotting patterns of cyst and trophozoite antigens were significantly different. Hyperimmune rat sera recognised two major proteins of 104 and $50-60 \mathrm{kDa}$ in cyst and trophozoite preparations, and an additional six bands with mol. wts between 60 and $90 \mathrm{kDa}$ were found only in preparations of trophozoites. This may reflect limitations in the antigenic repertoire of cysts or may be the result of poor solubilisation of resistant cysts compared to fragile trophozoites. Only one other study has attempted to isolate trophozoites and cysts and compare antigenic profiles by immunoblotting with antitrophozoite and anti-cyst rabbit antisera. ${ }^{4}$ These workers also reported differences in the antigen profiles of cysts and trophozoites: two major bands of 110 and $45 \mathrm{kDa}$ and a secondary band of $50 \mathrm{kDa}$ were associated with cysts; proteins of 30 and $48 \mathrm{kDa}$ and minor bands of 60,50 and $90 \mathrm{kDa}$ were associated with trophozoites. As anti-trophozoite and anti-cyst antisera showed the same pattern of reactivity, but a stronger intensity in species-specific reactions, the authors concluded that cysts and trophozoites had identical antigens present in different proportions. A high degree of cross-reactivity with the hyperimmune sera was found also in the present study but the $63-$ and $81-\mathrm{kDa}$ proteins were detected only in trophozoite-rich antigen with anti-trophozoite antisera, suggesting that they are trophozoite specific.

The 104- and 50-60-kDa bands detected in cyst and trophozoite-rich antigens by anti-cyst and antitrophozoite antisera are probably identical to the 116-, 50- and 45-kDa proteins which have been detected consistently in rat $P$. carinii in immunoblotting studies with sera from immunised rabbits. ${ }^{12,13}$ Bands corresponding to proteins of $60-90 \mathrm{kDa}$ have been demonstrated also, but they varied in clarity and intensity and were overlooked in favour of the more dominant bands in a study in which the parasites were not gradient-derived. ${ }^{13}$ Although the 63 - and $81-\mathrm{kDa}$ bands were detected in all the preparations that contained $\geqslant 90 \%$ trophozoites, the intensity of the bands varied; they were not detected in lung homogenates which had not been purified on Percoll gradients. This suggests that concentration is important, since the effect of Percoll gradient separation is to increase the numbers of parasites and reduce the host cell contamination in the preparations. ${ }^{9}$ The $63-\mathrm{kDa}$ protein ran very close to the $50-60-\mathrm{kDa}$ bands common to all preparations and was sometimes masked in intensely stained blots. The UC pellet preparation, which was completely devoid of cysts, confirmed the 
specificity of the $63-$ and $81-\mathrm{kDa}$ bands as markers of trophozoites.

There is some evidence that these bands may be specific markers of PCP. We and others have detected proteins of $50-60$ and $110 \mathrm{kDa}$ in control rat antigen preparations, ${ }^{14}$ suggesting they arise from rat proteins or cysts in normal lung. Bands in the $60-90 \mathrm{kDa}$ range were not detected in control antigen preparations. In an interesting study, lavage fluid from infected rats, centrifuged at $10000 \mathrm{~g}$ to remove any cysts, was probed with a pool of five anti- $P$. carinii monoclonal antibodies and bands of 66 and $90 \mathrm{kDa}$ were found in addition to the major bands of 110-116 and $50-60 \mathrm{kDa}^{12}$ Although a faint $66-\mathrm{kDa}$ band was detected in lavage supernate controls, suggesting that the band may not be specific for $P$. carinii, these antigens may be useful markers of early PCP, since they were detected in the absence of cysts. Furthermore, the study confirmed the association of these bands with trophozoites, as soluble antigen is much more likely to be derived from them than from cysts.

In some studies, immunosuppression of rats to induce PCP prevented or suppressed antibody production and positive blots were obtained only when animals were allowed to recover. ${ }^{15} \mathrm{We}$ were able to detect antibody in sera from severely immunosuppressed rats, but only with trophozoite-rich antigen. The pattern of antigen recognition varied in individual animals; the $104-$ and $50-60-\mathrm{kDa}$ proteins that were detected are probably the same as the dominant $116-, 50$ - and $45-\mathrm{kDa}$ antigens identified by rat sera in other studies. ${ }^{1}$ Proteins of 81 and $63 \mathrm{kDa}$ were also detected. Antibodies were found to one or other of these antigens in 15 of 24 PCP-positive animals but in none of the 18 PCP-negative animals. Antibody to $60-92-\mathrm{kDa}$ antigens has been reported in serum from exposed and rats that recovered from PCP but not from normal rats, whereas proteins of 116,50 and $45 \mathrm{kDa}$ were recognised equally by normal, exposed and recovered rats. ${ }^{1}$ These results indicate

\section{References}

1. Chatterton JMW, Joss AWL, Davidson MM, Ho-Yen DO. Why have Pneumocystis carinii trophozoites been ignored? $J$ Clin Pathol 1990; 43: 265-268.

2. Masur H, Jones TC. The interaction in vitro of Pneumocystis carinii with macrophages and L-cells. J Exp Med 1978; 147: $157-170$

3. Walzer PD, Rutledge ME, Yoneda K, Stahr BJ. Pneumocystis carinii: new separation method from lung tissue. Exp Parasitol $1979 ; 47: 356-368$

4. Ishimaru T, Shimono N, Sawae Y, Niho Y. Purification of Pneumocystis carinii trophozoites and identification of their circulating antigens. J Clin Microbiol 1992; 30: 3263-3267.

5. Gosey LL, Howard RM, Witebsky FG et al. Advantages of a modified toluidine blue $O$ stain and bronchoalveolar lavage for the diagnosis of Pneumocystis carinii pneumonia. J Clin Microbiol 1985; 22 : 803-807.

6. Chatterton JMW, Joss AWL, Williams H, Ho-Yen DO. Pneumocystis carinii antibody testing. J Clin Pathol 1989; 42: $865-868$

7. Laemmli UK. Cleavage of structural proteins during the assembly of the head of bacteriophage T4. Nature 1970; 227: $680-685$. that the latter antibodies are markers of past as well as current infection, and that antibodies directed against the 81 - and 63-kDa antigens may be more specific markers of current infection. This pattern of antibody development is consistent with the 104- and 50 $60-\mathrm{kDa}$ antigens being common markers of cysts and trophozoites and the $81-$ and $63-\mathrm{kDa}$ antigens being trophozoite specific, since trophozoites predominate in active infection.

Effective treatment of human PCP depends upon early diagnosis. The demonstration of $P$. carinii in bronchoalveolar lavage or induced sputum has improved with the availability of monoclonal antibodies and the polymerase chain reaction (PCR). Diagnosis with PCR has the advantage that it is sensitive and may be positive before there is a serological response. However, methods demonstrating $P$. carinii rely on potentially hazardous invasive procedures to obtain suitable specimens. ${ }^{16}$ Furthermore, the presence of $P$. carinii does not always equate with clinically significant disease, ${ }^{17-19}$ whereas the demonstration of a serological response can be more helpful. ${ }^{6,17,18}$ Although serological testing is simpler, the available tests are of limited value because of poor sensitivity or specificity., ${ }^{1,6}$ Many investigators have highlighted the need to identify specific antigens which might be exploited for diagnostic purposes. So far, Western immunoblotting studies have identified reactive proteins of 40,66 and $82 \mathrm{kDa}$ in human $P$. carinii but antibodies to these proteins are found in serum from healthy subjects as well as PCP patients, so that they are of limited diagnostic use. ${ }^{1}$ The results described in this paper indicate that serological tests based on the detection of antibodies directed against trophozoite antigen might be diagnostically useful.

We thank R. Evans, D. Ashburn and Lesley Dargie for their assistance and helpful co-operation; Lorna Wycherley for invaluable secretarial assistance; and the Scottish Home and Health Department (SHHD Grant No. K/CSO/2/20/2/2) for financial support.

8. Towbin H, Staehelin T, Gordon J. Electrophoretic transfer of proteins from polyacrylamide gels to nitrocellulose sheets: procedure and some applications. Proc Natl Acad Sci USA $1979 ; 76: 4350-4354$.

9. Gradus MS, Ivey MH. An improved method of isolating Pneumocystis carinii from infected rat lungs. $J$ Parasitol 1986; 72: 690-698.

10. Read JA, Burns SM. A simple method of separation of Pneumocystis carinii from rat lung. Int J Exp Pathol 1991; 72: 673-677.

11. Watanabe J, Tanabe K, Shimada K. Separation of trophozoites of Pneumocystis carinii from lung of the inoculated nude rat. Jpn J Exp Med 1987; 57: 295-297.

12. McNabb SJN, Graves DC, Kosanke SD, Moyer MJ, Ivey MH. Pneumocystis carinii antigen detection in rat serum and lung lavage. $J$ Clin Microbiol 1988; 26: 1763-1771.

13. Walzer PD, Linke MJ. A comparison of the antigenic characteristics of rat and human Pneumocystis carinii by immunoblotting. J Immunol 1987; 138: 2257-2265.

14. Graves DC, McNabb SJN, Worley MA, Downs TD, Ivey MH. Analyses of rat Pneumocystis carinii antigens recognized by human and rat antibodies by using Western immunoblotting. Infect Immun 1986; 54: 96-103.

15. Walzer PD, Stanforth D, Linke MJ, Cushion MT. Pneumocystis carinii: immunoblotting and immunofluorescent analyses 
of serum antibodies during experimental rat infection and recovery. Exp Parasitol 1987; 63: 319-328.

16. Malin AS, Miller RF. Pneumocystis carinii pneumonia; presentation and diagnosis. Rev Med Microbiol 1992; 3: 80-87.

17. Ho-Yen DO, Chatterton JMW, Joss AWL. Pneumocystis carinii pneumonia. $B M J$ 1988; 297: 855 .
18. Chatterton JMW, Ho-Yen DO. Laboratory investigation of Pneumocystis carinii pneumonia. Genitourin Med 1992; 68: 336-341.

19. Contini C, Romani R, Vullo V, Delia S, Sorice F. Does laboratory recovery of Pneumocystis carinii always mean clinically significant disease? AIDS 1992; 6: 1558-1559. 